\title{
O CONTRATO DE ADMINISTRAÇAO. SUA NATUREZA E POSSHBLLIDADE DE CUMULAÇÃO COM UM CONTRATO DE TRABALHO
}

\author{
António José Samento de Oliveira
}

\section{INTRODUCAO}

As sociedades, enquanto pessoas colectivas, dispõem de um particular "modo de ser ou forma de vida", reflexo da sua abstracção, carente, por isso, de concreção. Essa concreção alcança-a a ordem jurídica pottuguesa através da técnica de recurso a órgãos, entendendo-se estes como centros institucionalizados de poderes funcionais, a serem exercidos, fatalmente, por pessoas físicas, instrumentos necessários para permitir que a sociedade ou pessoa colectiva tenha vontade e possa actuar. Haverá, assim, que distinguir entre o órgão e o titular do órgão e, consequentemente, admitir a existência de dois sujeitos: um a pessoa física - titular do órgão - que é o autor psicológico da vontade; outro a pessoa colectiva a quem essa vontade é imputada pelo Direito.

Ora se não há relação entre a sociedade e o órgão, já existe relação entre o órgão e o titular desse órgão, o «portador de organicidade».

Neste trabalho iremos centrar-nos, unicamente, na análise da relação de administração, isto é, da relação inter-subjectiva entre of $(s)$ titulare(s) do órgão de administração e a sociedade². A primeira questão a analisar é a da natureza do acto constitutivo da relação de adminis-

\footnotetext{
${ }^{1}$ Cf. Ilidio Duarte Rodrigues, A administracăo das Sociedades por Quotas e anónimas - Organizaçāo e Estatuto dos Administradores, Lisboa, Liv. Petrony, 1990, p. 275.

2 Designados pelo Código das Sociedades Comerciais (CSC) como gerentes nas sociedades por quotas (art. $252{ }^{\circ}$ do CSC), administradores ou directores, nas sociedades anónimas, consoante a estrutura de administraçấo e fiscalizaçäo adoptada (arts. 278.", n..$^{\circ}$, als. a) e b), e $3900^{\circ}$ e $424 .^{\circ}$, todos do CSC).
} 
tração. A segunda é a da espécie de contrato ou negócio unilateral ou de facto jurídico em que se integra. A terceira é a da admissibilidade de cumulação, na mesma pessoa, da qualidade de sujeito de uma relação de administração com a de sujeito de uma relação emergente de um contrato de trabalho celebrado com mesma sociedade.

\section{NATUREZA DO ACTO COFSTTTUTVYO DA RELACÃO DE ADMINISTRAÇAO}

A natureza do acto constitutivo da relação de administração depende fundamentalmente da sua estrutura ${ }^{3}$. A doutrina divide-se em três correntes fundamentais: as teorias do acto unilateral, a teoria contratualista e as teoria eclética ou de união de negócios (negócio unilateral e contrato $)^{4}$.

\subsection{Teorias do acto unilateral}

Para tais teorias a relação de administração tem como fonte ou um acto unilateral ou dois actos unilaterais. Um só acto unilateral para quem, como FERRARA JR., entende que para formação daquela relação de administração basta a nomeação pela sociedade, não sendo necessária a aceitação do nomeado ${ }^{5}$. Dois actos unilaterais para quem reconhece, em cada caso, dois actos, a nomeação e a aceitação, com diversos sujeitos, mas relacionando-se no sentido de o segundo ser condição de eficácia do primeiro.

Comum às duas posições é, assim, constituir a nomeação um acto unilateral relativo à organização da sociedade que, enquanto se consubstancia numa deliberação da assembleia, representa um acto interno. Divergem, como se referiu, quanto à necessidade de aceitação pelo

\footnotetext{
${ }^{3}$ Cfr. Luís Brito Correia, Os Administradores de Sociedades Anónimas, Coimbra, Almedina 1993, p. 416.

‘ Cfr, llídio Duarte Rodrigues, ob. cit., p. 265; Luís Brito Correia, ob. cit., p. 416.

${ }^{5}$ Apud Raíl Ventura, Sociedade por quotas, Vol. III - Comeniário ao Código das Sociedades Conerciais, Coimbra, Almedina 1991, p. 29. Como refere este lilustre ProFessor, não se entende bem a posição de Ferrara Ir. pois, começando por afitmar que a lei prescinde da aceitação do nomeado, vem depois a afimar que a lei presume essa accitação.
} 
nomeado, aceitaçăo essa, no entanto, que constitui, também, por sua parte, um acto unilateral o qual, relacionando-se com o primeiro, provoca plenamente a sua eficácia. A relação de administração surge, assim, para esta doutrina, pelo concurso da deliberação de nomeaçāo -.. acto interno - e da aceitação do nomeado, não pelo encontro de duas manifestações de vontade, a da sociedade e a do nomeado, consubstanciando a primeira uma proposta e a segunda uma aceitação.

\subsection{Teoria contratualista}

Para esta corrente a relação de administração nasce de um contrato, resultado da fusão de duas declaraçōes de vontade, sendo uma a nomeação pela sociedade e a outra a aceitação pelo nomeado.

Esta teoria pressupõe, logicamente, que o acto de nomeação, quando constitua uma deliberação, produza efeito externo ${ }^{6}$, valendo, por isso, relativamente ao nomeado como proposta contratual. A aceitação por este da proposta, efectuada por forma expressa ou tácita, completa o contrato.

\subsection{Teoria ecléctica ou de uniño de negócios}

A doutrina em apreço distingue dois actos, geradores de outras tantas relações jurídicas.

Um, a nomeação pela sociedade, acto jurídico unilateral de natureza corporativa, fonte da relação orgânica, O outro, acto jurídico bilateral ou contrato, de natureza obrigacional, fonte da relação de serviço ou relação de emprego.

Pelo primeiro é atribuído a qualidade de titular de órgão ao nomeado, ficando, por isso, este investido na competência atribuído, por lei, a esse órgão e sujeito aos correspondentes deveres.

Pelo segundo, são reguladas as relaçōes pessoais entre o administrador e a sociedade, maxime o dever de agir no interesse da sociedade e o direito de perceber uma remuneração.

E apesar de, quer pelos seus sujeitos quer pelos seus objectos, estarem relacionados, esses dois actos näo deixam, como se disse, de criarem duas relações jurídicas separadas.

'Cfr. Raúl Ventura, ob. cit., p. 30. 


\subsection{Posiçăo adoptada}

A teoria que, face ao nosso direito positivo, melhor traduz a natureza do acto constitutivo da relação de administraçäo é, a nosso ver, a teoria contratualista.

As teorias do acto unilateral năo nos parecem ser de aceitar. A corrente que sustenta só ser necessário e suficiente o acto unilateral da sociedade de nomeação, desde logo por, face à nossa lè, não existir um dever do nomeado - só equacionável se esse nomeado fosse sócio? - de exercer as funções inerentes ao órgão; por outro lado, impor-se-ia, também, a sujeição completa do nomeado (sócio) a todas as condições de exercício unilateralmente ditadas pela sociedade, o que se mostra, só por si, inaceitável.

Quanto à segunda conente que defende a existência de dois actos unilaterais, a nomeação pela sociedade e a aceitação pelo nomeado, sendo este condição de eficácia do primeiro, dir-se-á que o primeiro nomeação - é apenas apto a produzir, por si só, a atribução de poderes de gestão e representação da sociedade mas não a imposição de deveres, como o dever de agir no interesse da sociedade, nem a atribuição de direitos. Para esta imposição é essencial, como requisito de existência - e não somente de eficácia -, uma declaração de vontade do nomeado. No âmbito do direito privado não pode uma pessoa impor deveres a outra sem o consentimento desta".

Quanto à teoria ecléctica ou da união de negócios, pensamos, com Raúl Ventura ${ }^{10}$ que nada existe no Código das Sociedade Comerciais que leve a concluir ter sido a gerência ou a administração estruturada com base numa dupla relaçäo jurídica, com fontes diversas. Por outro

\footnotetext{
${ }^{7}$ Dever esse do sócio com origem ou na lei ou no contrato de sociedade. Quanto a tercerros, a imposiçăo do dever prescinctindo da sua vontade, representaria uma violaçăo grave ao princípio fundanental da altonomia da vontade.

${ }^{8}$ Nas sociedades por quotas, anónimas, nos termos do arts $252 .^{\circ}$, n. ${ }^{\circ}$, e $390^{\circ}$, n. 3 , do CSC, respectivamente, podicm ser gerentes/administradores, sócios e näo sócios. Já quanto à sociedade em nome colectivo, dispỏe o art. 191. do CSC que todos os sócios serão, em princípio, gerentes. Todavia nada impede que se disponha diferentemente no contrato social.

${ }^{9}$ Cf. Luís Brito Correia, ob. cit, pp. 469 e seg. , Raúl Ventura, ob. cit., p. 33.

${ }^{10}$ Ob. cit. p. 33.
} 
lado, a referência no art. $430 . ", n .{ }^{\circ} 3$, do CSC ao "contrato" $"$, para a determinaçăo do modo de fixaçăo da remuneração nada prova em sustentação da tese do duplo negócio jurídico. O que prova, sim, é que existe contrato e năo que esse contrato seja algo diverso do negócio jurídico pelo qual se nomeia o titular do órgão em questão.

Contra a teoria contratualista, que vê, como se disse, a designação como proposta contratual, não colhem, a nosso ver, as críticas que lhe têm sido feitas.

E desde logo näo colhe o argumento de a designação se fazer, normalmente, por deliberação de um órgão colegial, com carácter interno. Pois, sendo certo que a deliberação de designaçăo, como refere Raúl VENTURA 12 "se destina a realizar a estrutura intema da sociedade, a fornecer substrato a um órgão da sociedade que, por isso, é interno", não é menos certo que "essa escolha projecta-se, contudo, para o exterior, porquanto não basta a sociedade escolher, para o cargo estar preenchido; é necessário que o escolhido aceite e que, portanto, a deliberação só atinja o seu fim se, simultaneamente com a escolha, fizer o necessário para que se efective, ou seja, que proponha ao escolhido a aceitação da escolha".

E mesmo que a designação proceda não de deliberação de um órgão colegial, mas sim de um sócio ou grupos de sócios, possível nas sociedades por quotas, nos termos do art. $252^{\circ}, \mathrm{n} .{ }^{\circ} 2$, in fine, do CSC e mesmo nas sociedades anónimas, no caso previsto no art. $392{ }^{\circ}, \mathrm{n} .^{\circ} \mathrm{S}$ 6 e 8, do CSC, năo será de af́astar o carácter de proposta contratual da designação, cujo sujeito é sempre a sociedade. Uma coisa é a escolha ou selecção da pessoa para titular do órgão, outra, bem diferente, é o provimento dessa pessoa nesse cargo. E este constitui um acto da sociedade.

Por último, também não nos parece proceder o argumento de que a titularidade do órgão não pode ser objecto de relação contratual, por o seu conteúdo estar predeteminado pela lei. O facto de a lei regular, até imperativamente, os poderes e mesmo os direito e deveres dos titulares

11 Visto por Ilídio Duarte Rodrigues, ob. cit., p. 271, como a consagraçāo, pelo CSC, da distinção entre instalação do órgão administrativo e a relação de serviço entre o admi nistrador e a socjedacte.

I? Ob. cit., p. 32. 
do órgão de administração não significa que a relação inter-subjectiva entre o titular do órgăo e a sociedade não tenha uma origem contratual, na qual, aliás, ao abrigo do princípio da autonomia da vontade privada, outros direito e deveres podem ser estipulados. Significa, apenas, que, neste domínio, a lei impõe limites à liberdade de estipulação dos particulares, atendendo aos interesses dos sócios e de terceiros. As fontes dos poderes, direitos e deveres dos titulares dos órgãos de administração, que tanto podem ser a lei, contrato de sociedade, deliberações dos sócios ou o contrato de administraça distingue-se bem do facto gerador da relação inter-subjectiva, cujo conteúdo esses direitos e deveres integram. A concepção contratualista, nas palavras de RAúl VENTuRA ${ }^{13}$ "năo tem que ser levada ao ponto do nomeado aprovar o órgão de que vai ser titular, e todos os pormenores da respectiva regulamentação legal".

\section{CARACTEREACAO DO CONTRATO DE ADMINIS- TRACAO}

Dado por assente que a relação de administração tem por fonte um contrato, impóe-se, agora, indagar da natureza desse contrato.

A doutrina tem qualificado o contrato de administração ou como contrato de mandato, ou como contrato de prestação de serviços, ou, mais raramente, como contrato de trabalho subordinado. Ao confronto com estes tipos contratuais nos iremos ater, na tentativa de caracterização do contrato de administração.

Nesse confronto com as de cada um desses tipos contratuais, iremos utilizar as características essenciais do contrato de administração considerando ${ }^{14}$ :

a) a dualidade das partes;

b) a atribuição do poder e a assunção da obrigação do gerente e administrador exercer a actividade de modo mais ou menos autónomo, por conta e no interesse da sociedade;

c) a onerosidade ou gratuitidade.

13 Ob. cit., p. 33 .

${ }^{14}$ Seguimos, assim, a metodologia adoptada por Luís Brito Correia na sua obra já citada "Os Administradores de Sociedades Anónimas", obra essa que, neste particular seguimos de perto. 


\section{A) Duatidade de partes}

Comum aos contrato de mandato, prestaçăo de serviços e de trabalho subordinado, é o facto đe existirem, por regra ${ }^{15}$, só duas partes singulares. Quando de um dos lados existe mais do que uma pessoa, de algam modo relacionadas entre si, entende-se que há também uma pluralidade de contratos (art. $11600^{\circ}$ do CC).

O mesmo se passa relativamente ao contrato de administração. De um lado, encontra-se a sociedade, ente dotado de personalidade jurídica; do outro, o gerente ou administrador. E neste particular não haverá que distinguir consoante a nomeação resulte de deliberação dos sócios, caso em que a sociedade é representada pelo órgăo " conjunto de sócios ou assembleia-geral"16, daquelas situaçōes, possíveis nas sociedades por quotas e nas sociedades anónimas - clr. arts. $252 .{ }^{\circ}, \mathrm{n} .{ }^{\circ} 2$, in fine e $392 .^{\circ}$, n. ${ }^{\circ}$ s 6 e 8 , do CSC -, em que a designação é deferida, pelo contrato social, a alguns ou algum sócios ou se opera por qualquer outro modo. Também nesses casos, atendendo, como se disse à distinção entre designação para o órgão e provimento no órgão, parte no contrato de administração celebrado é a sociedade, representada, neste caso, pelo orgão com poder de representação. ${ }^{17}$

${ }^{15}$ E dizenos por regra pois quanto ao contrato de trabalho e como decorre da sua tefinição legal (art. $100^{\circ}$ do C.T.) admite-se hoje expressamentc a possibilidade de um trabalhador se vincular, pelo mesmo contrato, a prestar o sel trabaltho a uma piruralidade de empregadores. No eníanto, tal possibilidade está, nos termos do art. 92." do C.T., restrita às situações em que exista entre os vários empregadores ama relação societảia de participações recíprocas, de domínio ou de grupo ou que, independentemente da natureza societátia, mantenbam estruturas organizativas comuns.

${ }^{15} \mathrm{O}$ ģue năo fica prejudicado pelo facto de, no caso, só um sócio participar na deliberação, nem pelo facto de o gerente oú ad́ministrador participar na deliberação da sıa eleiçăo. Tanto num caso como no outro, quem elege não é o sócio mas a sociedade, representada pelo seu órgão "assembleia geral".

$17 \mathrm{O}$ órgão com competência de representação da sociedade ć, nas sociedades por quoias e nas sociedades anónimas, na estrutura dualista, com exclusividade, a getência e o conselho de administração, respectivamente (arts. $252 .^{\circ}, \mathrm{n} .^{\circ} 1, \mathrm{e} 405^{\circ}, \mathrm{n} \cdot{ }^{\circ} 2$, do CSC). Assim, no caso, ou já existe órgäo em condiçōes legais de poder funcionar e nesse caso a sociedade seria representada na celebração do contrato de administração por ele, ou o órgão não está cm condições de funcionar, por inexistência de titulares c nesse caso a sociedade seria representada por qualquer socio, que assumiria poderes de gestão e representaçấo da sociedade (art. $253{ }^{\circ}, n^{\circ}{ }^{\circ} 1$, do CSC). 
No caso de serem eleitos, numa mesma votação, vários gerentes ou vários administradores ${ }^{1:}$, sufragamos o entendimento de Luís Brito Correta ${ }^{\text {ly }}$ de que, juridicamente, há um contrato de administração com cada um deles, eventualmente interligados pela sujeição a condição suspensiva ou resolutiva, de existência ou manutenção de todos e cada desses contrato de administração.

Assim e concluindo, neste ponto näo existe diferença alguma entre o contrato de administração e os contratos de mandato, de prestação de serviços e de trabalho subordinado.

B) Obrigaçăo de exercício de actividade por conia e em nome da sociedade, com relativa autonomia

$O$ contrato de administração tem um objecto, por assim dizer, ambivalente. Engloba, por um lado, a atribuição de poderes para a prática de actos jurídicos em nome e por conta da sociedade; por outro lado, inclui, também, a obrigação de exercer certa actividade.

1. Não sofre dúvidas que a obrigação dos gerentes e administradores de gerir ${ }^{20}$ a actividade social representa uma obrigação de actividade que não de resultado. É certo que os gerentes e administradores têm um dever de diligência (art. 64. ${ }^{\circ}$ do CSC), o que significa a obrigação de aplicar um certo grau de esforço no sentido de realizar o interesse social, tipicamente, o de realizar o máximo de lucro. Mas năo têm, em princípio, que alcançar certo montante de lucro, lucro esse, aliás, que, como é sabido, depende de muitos factores, muitos deles fora do controlo dos administradores. Todavia, não fica excluida a possibilidade de fixação de objectivos aos gerentes e administradores, objectivos esses que a não serem atingidos podem implicar a extinção da relaçäo de ad-

\footnotetext{
"No caso das sociedades anónimas, tal será a regra. Na realidade, fora a situação de idmintstrador único, possível, nos termos do art. 390." n." 2 , do CSC, se a socicdade năo tiver capital social stuperior a 200.000 enros e cxistit cláusula no contrato de sociedade nesse sentido, o consello de administração, nos temos do art. $390{ }^{\circ}, \mathrm{n} .{ }^{\circ} \mathrm{l}$, do CSC, terá que ter um número impar e plural de membros. Por outro lado, a regra na eleição dos administradores é o sistema de listas, isto é, de cleição integral de todos os membros do conselho de administração, propostos em listas, cono resulta, implicito, do art. 392." do CSC.

${ }^{19} \mathrm{Ob}$. cit., p. 521 .

26) Alias, gerir é praticar toda una série de actos com un objectivo comum e nesse sentido é una actividade.
} 
ministração, por destituição por justa causa.

Esta diferente natureza da obrigação leva a distinguir o contrato de administração do contrato de prestação de serviços e dentro dele do contrato de mandato e a aproximá-lo do contrato de trabalho.

$\mathrm{Na}$ verdade, perante o Código Civil (arts. $1152 .^{\circ} \mathrm{e} 1154{ }^{\circ}$ ), o contrato de prestação de serviços, de que o mandato é uma espécie (art. $1154 .^{\circ}$ do CC), tem por objecto um resultado, năo uma actividade em $\mathrm{si}^{21}$. No contrato de prestação de serviços e no contrato de mandato, o prestador do serviço e o mandatácio não se limitam a pôr a sua capacidade de trabalho à đisposição do credor ou do mandante. Pelo contrário, eles assumem uma obrigaçấo de um resultado previamente determinado com maior ou menor rigor. Por outra banda, uma das caracteristicas essenciais do contrato de mandato, nos termos do art. $157 .^{\circ}$ do $\mathrm{CC}$, - qque não já do contrato de prestação de serviços no qual a prestação devida tanto pode consistir em actos jurídicos como em actos materiais - consiste na obrigação de o mandatário praticar actos jurídicos, enquanto a administração de uma sociedade tanto inclui a prática de actos jurídicos como de actos materiais.

Já no contrato de trabalho aquilo a que o trabalhador se obriga é a prestar a sua actividade intelectual ou manual à entidade patronal, sob a autoridade e direcção desta (art. $11520^{\circ}$ do $\mathrm{CC}$ e art. $100^{\circ}$ do Código do Trabalho). Esta obrigação, como aliás a do gerente e administrador, é uma obrigação primária, isto é, traduz-se numa obrigação de adoptar um comportamento e não de simplesmente permitir um comportamento alheio, como é, também, como a do gerente e administrador, uma obrigação de facere, uma prestaçăo de fazer algo. Por outro lado, essa actividade a que se obrigou o trabalhador tanto pode ser manual como intelectual e tanto pode concretizar-se na prática de actos materiais como de actos jurídicos, pelo que, iguaImente nestes aspectos, năo se diferencia

\footnotetext{
${ }^{21}$ A distinçăo enfre obriğação de prestar tına actividade e obrigação de prestar um resultado consiste, fundamentalmente, em na primeira o clevedor se obrigar à pratica de certo tipo de actos ou série de actos que se identificam por referêncià à sua estrutura e na segunda, tipicamente, o devedor se obrigar a entregar ou realizar uma obra, produto ou serviço em condiçōes de satisfazer o interesse do credor. De precisar, no entanto, que quando o resultado a que se obriga o devedor é completamente inseguro, na dúvida, só se considera vinculado ao resultado que resulte imediatamente da boa execução técnica da actividade desenvolvida e nẩo ao seu rcsultado favorável.
} 
ou pode não se diferenciar do contrato de administração.

II. O exercício da actividade a que está obrigado o gerente e administrador é um exercício por conta de terceiro, no caso, a sociedade.

No contrato de mandato, como resulta do art. 1157. . do CC, o mandatário actua no interesse do mandante, sem prejuizo de poder actuar, conforme se extrai do art. $11700^{\circ}, \mathrm{n} .^{\circ} 2$, do $\mathrm{CC}$, também, no próprio interesse do mandatário ou de terceiro, no que se afasta dos restantes contratos. No contrato de prestação de serviços, a situação é idêntica (art. $1156{ }^{\circ}$ do CC). No contrato de trabalho, o trabalhador obriga-se a prestar uma actividade no interesse da entidade patronal, que se apropria da mais valia desse trabalho. Por último, no contrato de administração, o gerente e administrador e nos termos do art. 64. ${ }^{\circ}$ do CSC, deve actuar no "(...) interesse da sociedade, tendo em conta os interesses dos sócios e dos trabalhadores" 2223 .

Neste particular, o contrato de administração não se distingue dos contratos de prestação de serviços, mandato e de trabalho subordinado.

III. Já quanto à actuação em nome de outrem, verificam-se diferenças relevantes entre o contrato de administração e os contratos de prestação de serviços, mandato e de trabalho subordinado.

Diga-se desde já que, na esteira de Inocênclo Galvão Telles ${ }^{24}$, entendemos que pode haver mandato sem representação e representação sem mandato, podendo assim a concessão de poderes de representação ser realizada quer por acto unilateral - procuração - ou em conjunto com vários tipos de contrato: mandato, contrato de trabalho ou mesmo certas espécies de contrato de prestação de serviços que se não enquadram, propriamente, num contrato de mandato ${ }^{25}$.

\footnotetext{
${ }^{22} \mathrm{O}$ que seja o interesse da sociedade em que nedida é que se diferencia do interesse dos sócios é questão controvertida. Vd., por todos, Lobo Xavicr, Anulação de Deliberaf̧ão social e Deliberaçöes Conexas, pp. 168 es. e nota 76 e pp. 242 e ss. e nota 116.

73 É deste dever de actuação por conta da socjedade que decorre o dever do gerente ou administrador de prestár contas (art. 65. do CSC), de prestar informaçóes (arts. 214.", $290{ }^{\circ} \mathrm{c} 291 .{ }^{\circ}$ do $\mathrm{CSC}$, o dever de indemnizar a sociedade (art. $72{ }^{\circ} \mathrm{do}$ CSC).

24 Contratos Clyis, in BMJ, n. ${ }^{\circ} 83$, pp. 173 ess.

25 Nomeadamente, pelo facto da prestaçăo do prestador do serviço não se esgotar na prática de actos juridicos.
} 
A representação da sociedade pelos seus gerentes e administrado. res, o que influencia todo o seu regime, é uma representação orgânica. Como se disse, as sociedades são pessoas colectivas, o que implica um particular modo de ser ou forma de vida, carente de concreção. Essa concreção, também como se disse, realiza-a a ordem jurídica através de órgãos. Ora, a diferença fundamental entre a actuação do órgão - representação necessária - e a actuaçấo do mandatário - representação voluntária - reside aa circunstância de o acto do órgäo ser imputado directamente à pessoa colectiva enquanto o acto do mandatário é sempre um acto do mandatário, imputando-se ao mandante somente os seus efeitos e não o acto em si ${ }^{26}$. Enquanto a pessoa colectiva não tem senão a vontade dos seus órgãos, nẫo substituindo, por isso, os seus titulares essa vontade antes a expressando, já na representaçẽo voluntária, a vontade do representante substitui-se à vontade do representado, sendo, como se disse, a vontade imputada a ele representante es efeitos dessa vontade ao representado.

Desta diferença fundamental decorre outra diferença importante entre o contrato de administração e o de mandato. Neste, o mandante mantém os poderes de agir que confere ao mandatário, podendo, por isso, se o quiser, praticar ele próprio os actos objecto do mandato. Diversamente, com a celebração do contrato de administração, os gerentes e administradores adquirem poderes que nem os sócios nem nenhum outro órgão tem nem pode ter. $\mathrm{E}$ se quanto aos poderes de gestão da sociedade permite a lei, em grau e amplitude variável, consoante o tipo de sociedade, a intervenção dos sócios on de outros órgãos ${ }^{27}$, já quanto à representação da sociedade, a gerência e o conselho de administração tềm, nos termos dos arts. $252 .^{\circ}$, n. $^{\circ} 1$, e $405 .^{\circ}, n^{\circ}{ }^{\circ}$, do CSC, exclusivos poderes de representação. Aqui, os sócios não conferem poderes aos gerentes e administradores, limitando-se a designar as pessoas que, por força da lei, passam a deter esses poderes. Poderes esses que săo, em

\footnotetext{
${ }^{26}$ Referimo-nos, aqui, tmicamente ao mandato com representaçăo, ssto ć, aquele em que o mandatário tem o dever de agir, não só por conta, mas em nome do mandante, a nắo ser que outra coisa tenha sido estipulada (art. 1178." do CC). Quanto ao mandato sem representação, pelo contrário, o mandatário age por conta do mandante mas em nome próprio.

${ }^{27} \mathrm{Vd}$ art. $259 .^{\circ}$, para a sociedade por quotas, e art. $405 .^{\circ}$ e $431 .^{\circ}$, para a sociedade anónima.
} 
grande medida, poderes legais, sendo, assim, aqui, reduzida a autonomia da vontade das partes na determinaçẫo do conteúdo da relação de administração, enquanto que na representação voluntária o conteúdo dos poderes de representação se determina pela vontade das partes.

Pela mesma razão de do contrato de administraçāo derivarem, por força da lei, poderes de representaçăo necessária, enquanto nos contrato de mandato, de prestação de serviços e de trabalho subordinado os poderes de representação derivarem de uma concessäo voluntária $\mathrm{da}$ parte e com os limites dessa concessão, decorre que, em princípio, os gerentes, administradores e directores não se podem fazer substituir, no exercício do seu cargo, por terceira pessoa (arts. $252 .^{\circ}$, n. $^{\circ} 5,391 .^{\circ}$, n. ${ }^{\circ} 6$, e $425 .^{\circ}$, n. $^{.4}$, do $\mathrm{CSC}$ ), enquanto que na representaçẫo voluntária essa substituição fica dependente da vontade do representado, que a pode permitir (arts. $264{ }^{\circ}$ e $1165^{\circ}$ do CC).

IV. É, no entanto, a grande autonomia com que os gerentes e administradores ${ }^{28}$ exercem as suas funções que é arvorada, pela doutrina e pela jurisprudência, como a característica do contrato de administração, permitindo diferenciá- lo dos contratos de mandato, de prestação de serviços e de trabalho subordinado.

Quanto ao mandato dispõe o art. 1161.., n. $1 . \circ$, al. a), do CC que "o mandatário é obrigado: a) A praticar os actos compreendidos no mandato, segundo as instruções do mandante". Daqui resulta que o mandatário, embora goze no exercício do seu mandato, de uma ampla autonomia, na medida em que está a satisfazer um interesse alheio - o do mandante - deve respeitar a vontade do mandante. Esta mesma subordinação à vontade conhecida do mandante está presente na definição legal de mandato comercial expressa no art, $238 .^{\circ}$ do C. Com.

Relativamente ao contrato de prestação de serviços, na medida em que o Código Civil não dispõe de qualquer disposição neste ponto, vale, nos termos do art. $1156 .^{\circ}$ do $\mathrm{CC}$, o regime do contrato de mandato, supra referido.

Já quanto ao contrato de trabalho a subordinação jurídica do trabalhador ao empregador, a par com a retribuiçăo, tem sido considerado o principal critério caracterizador.

A subordinação emergente do contrato de trabalho e que releva

${ }^{24}$ Mais estes últimos, como iremos ver. 
para a sua própria definiçăo, é uma noçăo jurídica, traduzida na possibilidade, atribuída pelo contrato à entidade patronal, de dar ordens a instruções sobre o modo como a prestação devida pelo trabalhador deve ser cumprida, mesmo que essas ordens não sejam formuladas. Importa a possibilidade jurídica de conformação da prestação devida pelo trabalhador, o poder de organizar a execução do trabalho.

Mas a subordinação jurídica năo se mostra incompatível com a autonomia técnica do trabalhador (art. $1120^{\circ}$ do C. T.). E essa autonomia fécnica pode existir ou porque a entidade patronal näo possui os conhecimentos científicos ou técnicos requeridos para o exercício dessa actividade ou porque existem regras deontológicas ou legais que são incompatíveis com a dependência técnica do trabalhador. Nesses casos, o trabalhador deve obediência à entidade patronal em tudo que não contenda com as regras técnicas, deontológicas ou legais da profissão daquele, constituindo, mesmo, um dever do empregador face ao trabalhador respeitar essa autonomia técnica (art. 120. ${ }^{\circ}$, al. e), do C.T.). Acresce que, nada impede a existência de estipulações contratuais que, embora não podendo excluir de todo o poder de organizar a execução do trabalho, podem, no entanto, excluir, completamente, o poder determinativo e conformativo da prestação do trabalho.

E é precisamente esta situação de afrouxamento ou exclusão do poder determinativo e conformativo da prestação do trabalho que torna difícil, na prática, a determinação da existência de subordinação jurídica numa determinada relação, fundamental para a qualificação como contrato de trabalho. Por isso, a doutrina e a jurisprudência têm tentado identificar "sinais" ou "índices" de subordinação jurídica, apontando como tais a vinculação do trabalhador a horário de trabalho, a existência de local de trabalho nas instalações do empregador ou em local por ele designado, a existência de controlo externo do modo de prestação da actividade, a obediência a ordens e a sujeição à disciplina da empresa, a retribução certa, à hora, đia, semana ou mês, a pertença dos instrumentos de trabalho ao empregador, a exclusividade da actividade laboral em benefício de uma só entidade, o regime fiscal e de segurança social ${ }^{29}$.

Quanto ao contrato de administração é inegável que dele deriva larga autonomia para os gerentes e administradores, cotados de compe-

${ }^{29}$ Cl. Luis Brito Corteia, ob. cit. pp. 554 e s., Ac. STJ de 17/2/94, in Acontāos Doutrinais do STA, Ano XXXII, Julho 1994, pp. 900 e ss., e acórdãos aí referidos. 
tência própria que os sócios têm que respeitar e năo podem, em princípio, invadir.

Atenta essa realidade parece não poder encontrar-se o gerente e administrador em posição de subordinação jurídica, característica essencial do contrato de trabaho.

Mas será mesmo assim?

V. Como se viu, a subordinação jurídica, como elemento caracterizador do contrato de trabalho, traduz-se numa noção bastante elástica, pois, por un lado, não é incompativel com a rotal independência técnica do trabalhador e, por outro lado, está dependente das proprias estipulações contratuais, com o único limite de não excluir o poder de organizar a execução do trabalho.

Ora, se bem que nos termos do art. $405^{\circ}, n^{\circ}$ I, do CSC, seja ao conselho de administração que compete "gerir as actividades da sociedade", deve aquele, no entanto, subordmar-se às deliberaçóes dos accionistas ou às intervençôes do conselho fiscal apenas, mas também sempre, quando "a lei ou o contrato de sociedade o determinarem". Daqui resulta que a subordinação dos administradores é, em matéria de gestão, muito variável. No silêncio do contrato e por força da lei, nos termos do art. $373 .^{\circ}$, n. ${ }^{\circ} 3$, do CSC, os accionistas só podern deliberar a pedido do órgão de administração e as intervenções do conselho fiscal limitam-se a actividades de fiscalização - arts. $4200^{\circ}$ e $421 .^{\circ}$ do CSC. No entanto, o contrato de sociedade pode estabelecer, com base no referido art. $405{ }^{\circ}, n . " 1$, do CSC, a subordinação do conselho de administração, em matéria de gestão, às deliberações dos accionistas e às intervenções do conselho fiscal. Esse dever de subordinação pode mesmo o contrato de sociedade consagrá-lo com grande amplitude, com o que näo haverá grandes diferenças com a situação dos trabalhadores subordinados, nomeadamente quanto seja reduzido o número de accionistas, que pode chegar a ser tum só (art. $4880^{\circ}$ do CSC)

E no caso dos gerentes essa subordinação ainda é ou pode ser mais patente, pois nos termos do art. 259." do CSC, se bem que seja aos gerentes que compete "praticar os actos que forem necessârios ou convenientes para a realização do objecto social" devem eles, porém, fazêlo, "com respeito pelas deliberaçōes dos sócios". Aqui, como resulta deste nomativo, consagra a lei um direito dos sócios intervirem em 
matéria de gestão, estabelecendo, correlativamente, um dever geral de subordinação dos gerente, no exercicio da sua competência de gestão da activitade da sociedade.

Se a esta situação aliarmos o facto de os gerentes poderem ser não sócios, porventura năo existirá, de facto autonomia mas sim uma situação de subordinação jurídica, aproximando o contrato de administração a um verdadeiro e próprio contrato de trabalho ${ }^{30}$.

E, acompanhando Irítro Duarte Robrigues ${ }^{31}$, também nắo se nos afigura de rejeitar, in limine, a possível qualificação do contrato de administração como contrato de trabalho pela circunstância de faltar à sociedade o poder disciplinar sobre o gerente e administrador e por não se poder devolver ao colégio dos sócios o poder directivo, dada a existencia de uma esfera de actividade respeitante inderrogavelmente à competência do gerente e administrador.

É que, como refere o mesmo autor, e quanto ao poder disciplinar, por um lado, questiona-se se ele é elemento essencial do contrato de trabalho subordinado e por outro lado, equaciona-se se a possibilidade de os gerentes e administradores poderem ser livremente destituídos ${ }^{32}$ sem direito a qualquer indemnização não constitui a consagração, precisamente, desse poder disciplinar da sociedade sobre os seus gerentes e administradores.

Já no que se refere à inexistência de poder determinativo, por se reconhecer aos gerentes e administradores uma esfera de competência exclusiva, haverá que dizer que, como já referido, esse poder determinativo não se revela essencial ao contrato de trabalho. Essencial é o poder de organizar a execução do trabalho. Acresce que, como também já referido, não existe incompatibilidade entre a subordinação jurídica e a total autonomia e independência técnica do trabalhador, a qual pode resultar, inclusive, de imposiçăo legal (art. 112. ${ }^{\circ}$ do C.T.).

Resumindo, tudo estará em saber, neste âmbito, como no contrato

\footnotetext{
31. Neste sentido Ac. do STJ de $20 / 1 / 82$, in BM.J, n. ${ }^{\circ} 323$, p. 406 e Ac. da Relação de Coimbra de 2/12/93, in CJ ano 93, tomo V, pp. 86 ess.

${ }^{31}$ Ob. cit., pp. 293 e ss.

32 Essa possibilidarte de destituição por vontade dos sócios näo é excluída pelo facto de existir um direito especial à gerencia, pois nos termos do art. $257^{\circ}, n{ }^{\circ} 3$, do CSC, a mesma é sempre possível, se bem que pelo Tribunal e com fundanento em justa causa e com precedĉncia de deliberaçäo social nesse sentido.
} 
de administração estão reguladas estas questões. Se à sociedade foi atribuído o poder de organizar a execução do trabalho, maxime pela fixação do tempo de trabalho a prestar e do modo de o executar, o contrato de administração podera ${ }^{33}$ constituir um próprio e verdadeiro contrato de trabalho.

\section{C) Onerosidade e granitidade}

Tanto o contrato de mandato como o de prestação de serviços podem ser gratuitos ou onerosos, presumindo-se aquele, nos termos do art $1158 .{ }^{\circ}$ do CC, gratuito, excepto se tiver como objecto a prática de actos que o mandatário pratique por profissão, caso em que, pelo contrário, se presumirá oneroso. Já quanto ao mandato comercial a regra é de que é oneroso (art. $232 .^{\circ}$ do C. Com.).

O contrato de trabalho é, por definição, oneroso, sendo, por isso, essencial a retribulção, como resulta do art. $1152 .^{\circ}$ do $\mathrm{CC}$ e do art, art. 10. ${ }^{\circ}$ do C.T.

Quanto ao contrato de administração, o CSC toma posição expressa relativamente aos gerentes das sociedades por quotas. Assim, nos termos do art, $255{ }^{\circ}$, n." 1 , "salvo disposição do contrato de sociedade em contrário, o gerente tem direito a uma remuneração, a fixar pelos sócios".

Já no que concerene aos administradores das sociedade anónimas, o CSC, neste particular, nada refere. Parece-nos, no entanto, que não se poderá inferir do silêncio da lei, que esta pressupõe que a remuneração é sempre devida ${ }^{34}$.

Assim, haverá que aplicar por analogia o art. $255^{\circ}$, n..$^{\circ} 1$, no sentido de admitir que não haja remuneração se o contrato de sociedade assim o permitir, mas seja devida no silêncio deste.

\footnotetext{
${ }^{33}$ Poderá constituir um contrato de trabalho, pois sempre haverá que se verificar, no caso, outra das características do contrato de trabatho, a seguir referida no texto - a retribuição.

${ }^{34}$ Em sentido oposto, Ilidio Duate Rodrigues, ob, cit, p. 137.
} 


\section{CUMULAÇA DE UM CONTRATO DE ADMINISTRA- ÇAO COM UM CONTRATO DE TRABALHO}

A questão que nos vai agora ocupar consiste em saber se é possível uma pessoa ser simultaneamente gerente ou administrador e trabalhacor da mesma sociedade ${ }^{35}$.

Contra essa possibilidade esgrime-se com o argumento da inexistência de vínculo de subordinação jurídica, dado trabalhador não poder estar subordinado a si mesmo, na veste de gerente ou administrador ${ }^{36}$.

No entanto, tal doutrina esquece que o gerente ou administrador não se confunde com a sociedade, näo é a entidade patronal mas simn órgão desta, podendo aquela ser representado por outro gerente ou administrador ou pela vontade colectiva da gerência ou administração para a formação da qual o gerente ou administrador trabalhador pode não ter um voto decisivo ou até năo votar de todo ${ }^{37}$.

Por outro lado, a lei admite, em certas condiçöes, o negócio consigo mesmo (art. 261. "do CC e art. 397.", n." 2 , do CSC, a contrario).

Do mesmo modo, não se pode esgrimir, contra a cumulação, com a impossibilidade absoluta de exercicio do poder patronal. Bastará, para o seu exercício, que a sociedade, representada pelos outros gerentes ou administradores despeça o trabalhador, ou quando isso não seja possível, destitua o gerente ot administrador e nomeie outro que o despeça. Acresce nas sociedades por quotas, a possibilidade de o colégio dos

\footnotetext{
${ }^{35}$ Essa cumulação pode realizar vátios interesses, quer da sociedade quer do gerente ou administrador quer mesmo dos trabalhadores, em geral. Realiza interesses da sociedade pois, por um lado, permite o recrutamento, para funções de administraçăo, de um trabaIhador com especiais aptidöes técnicas, facultando-lhe um modo de promoção na empresa sem que essa promoçăo implique a perda de benefícios decorrentes da legislação laboral e, por outro lado, possibilita confiar funçóes técnicas especiais, enn condiçōes te subordinaçăo, a tam gerente ou adminsstrador com aptidões patticulares. Realiza interesses dos gerentes ou administradores pois possibinita a estes gozar da estabilidade e da proteção que a lei dispensa aos trabalhadores. Por último, possibilita a realização de interesses dos traballadores, entendidos colectivamente, pois permite a eleição para a administração de representantes dos trabalhadores, sem que esses representantes percam essa condição de trabalhadores.

36. Vd Ac. do STJ de 15/10/80, in BMJ n, 227, pp. 1342 e ss.

${ }^{\exists 7}$ Neste sentido, Raúl ventura, ob. cit, p. 36; Luís Brito Correia, ob. cit. pp 375 e s.; llídio Duarte Rodrigues, ob. cit., p. 304.
} 
sócios, com base no art. $259 .^{\circ}$ do CSC, dar instruçōes vinculativas ao gerente-trabalhador:

Assim, se o gerente ou administrador já era trabalhador à data da designação para o cargo, tudo estará em se verificar, no caso, se é possível ou não subsistir a subordinação jurídica ${ }^{38}$, essencial ao contrato de trabalho, ao lado da qualidade de gerente ou administrador, a que é inerente uma certa participaçăo no poder de direcção. Necessário é, também, que o trabalhador continue obrigado, pelo contrato de trabatho, a prestar uma actividade que se distinga da actividade de gestão da sociedade.

Questão diversa, e que analisaremos em breve, traduz-se em saber se o contrato de trabalho mantém toda a sua eficácia ou se suspende ou mesmo cessa.

No caso do gerente ou administrador pretender celebrar um contrato de trabalho com a respectiva sociedade, para além da verificação da possibilidade de subordinação jurídica, a apurar caso a caso e de o objecto do contrato de trabalho consistir em prestação de actividade distinta da actividade de administração, tudo nos termos acima exposto, haverá que respeitar os limites da admissibilidade do negócio consigo mesmo, previsto no art. $261 .^{\circ}$ do CC.

Mas uma coisa é admitir a possibilidade de cúmulo, outra é determinar em que condiçôes pode ele verificar-se, porque, além do mais, haverá que prevenir situações de fraude ${ }^{39}$.

\subsection{Os Administradores das sociedades anónimas}

O Código das Sociedades Comerciais prevê, no art. $398 .^{\circ}$, n. ${ }^{\circ}$ s l e 2 , a questão da admissibilidade de cúmulo, relativamente aos adminis-

\footnotetext{
${ }^{33}$ Como referido supra no texto, a subordinaçāo jurídica basta-se com o poder de organizar a exccução do trabalho, podendo estar ausente, de todo, o poder determinativo e conformativo da prestaçäo de trabalho.

${ }^{39}$ É o caso de se celebrar um contrato de trabaho, com o únco fim de restringir o princípio da livre destituiçäo a todo o tempo do gerente ou administrador. Neste caso, o contrato de itabalho teria como única finalidade garantir ao gerente ou administrador a estabilidade de um posto de trabalho que the advén do princípio da proibiçăo de despedimentos sem justa causa.
} 
tradores das sociedades anónimas ${ }^{40}$.

Com efeito, dispôe o art. $398^{\circ}$, n. $\%$ s 1 e 2, do CSC:

"1. Durante o período para o qual foram designados, os administradores não podem exercer, na sociedade ou em sociedade que com esta esteja em relaçăo de domínio on de grupo, quaisquer funçōes temporárias ou permanentes ao abrigo de contrato de trabalho, subordinado ou autónomo, nem podem celebrar quaisquer desses contratos que visem uma prestaçāo de serviço quando cessarem as funçōes de administrador.

2. Quando for designado administrador uma pessoa que, na sociedade ou sociedades referidas no número anterior, exerça qualquer das funçōes mencionadas no mesmo número, os contratos relativos a tais funções extinguem-se, se tiverem sido celebrados há menos de um ano antes da designação, ou suspendem-se, caso tenham durado mais do que esse ano."

Deste normativo retira-se, sem mais, não ser admissível o cúmulo quando no momento em que se pretende realizar, o interessado já era administrador ou, sendo trabalhador, a relação de trabalho tenha durado menos de um ano. No primeiro caso, proíbe-se a celebração, ex novo, de contrato de trabalho; no segundo caso, determina-se a cessação do pré-existente contrato de trabalho ${ }^{4 !}$.

${ }^{40}$ Entendemos que apesar do art. 398." do CSC só se referir aos administradores serú de aplicar aos membros da Direcção das sociedites anónimas, na estrutura, dita, triparida. Na verdade, não vemos qualquer razāo para diferenciar, neste particulă, o regime de incompatibilidade e impedimentos dos administradores e directores. Em sentido contrário, llído Duarte Rodrigues, ob. cil., pp. 313 e ss.

4 O Acórdāo n. ${ }^{\circ} 1018 / 96$ do Tribunal Constitucional (publicado no DR te 13/12/96, II Série, pp. 17305 a 17307 ) julgou formalmente inconstitucional o n. 2 do art. 398 ." do $\mathrm{CSC}$, na parte em que consiclera extintos os contratos de trabalho, subordinado ou autónomo, celebrados há menos de um ano contados desde a data da designação de uma pessoas como administrador e a sociedade oti as sociedade que com aquela estejam en relaçāo de dominio ou de grupo, por ofensa por ofensa da al. d) do art. $55{ }^{\circ}$, e da alínea a), do $11,{ }^{\circ} 2$ do art. $57, "$ ambos da CRP, na versäo operada pela Lei Constitucional $\mathrm{n}^{\circ} 1 / 82$, de 30 de Setembro, pois considerou que esse n. 2 do art. $398^{\circ}$ do CSC, veio acrescentar ama nova causa de caducidade do contrato de trabalho, integrando-se, assim, no conceito de "legislaçäo do trabalho", para a qual é necessário a participação das comissōes de trabalhadores e das associaçoes sindicais, o gue se não verificon. No mesmo sentido da inconstitucionalidade formal e com os mesmos fundamentos, julgou o Ac, do STJ, de 22/10/97 (pubicado nos Acórdäos Doutrinais do STA, ano XXXVII, Março de 1998, pp. 406 e ss.). 
A proibiçăo do cúmulo destina-se a evitar que as regras, nomeadamente de proibição de despedimento sem justa causa, que garantem a estabilidade da relação laboral, restrinjam ou impeçam o funcionamento da regra da livre destituição, a todo o tempo, dos administradores, expresso no art $403 .^{\circ}$ do CSC.

Assim, resulta do mencionado art. $3980^{\circ}$ do CSC que o único cúmulo admissível é o que resulta de contrato de trabaho com mais de um ano de duração. E neste caso, com a importante consequência, de ficar suspenso o pré-existente contrato de trabalho durante o período de exercício do cargo de administrador.

Quanto ao prazo de um ano de duração do contrato de trabalho, da sua redacção resultam dúvidas quanto ao seu termo inicial e final. Relativamente ao primeiro a dúvida é se se deve contar o prazo de um ano da data de celebração do contrato de trabalho ou, pelo contrário, se deve contar esse ano do início de execução efectiva das funções subordinadas que the correspondam. Quanto ao termo final, a dúvida está em saber se basta a designação como administrador ou é necessário, também, o início efectivo das funções de administrador.

Quanto à primeira questão, parece-nos que a melhor solução, que tem a seu favor o elemento literal, é contar o prazo de um ano da data de celebração do contrato de trabalho, desde que tenha havido efectiva execução, isto é, que as funções subordinadas que lhe correspondam tenham sido efectivamente exercidas ${ }^{42}, \mathrm{com}$ a precisão de se contar desde o início de execução que não da celebração quando essa formalização tenha ocorrido em data posterior.

Quanto à segunda questão, parece-nos que o termo final deve contar-se da data de designação que não do início de funções de administrador:

Outra questão que levanta a solução expressa no art. $398^{\circ}$, n1. 2 do CSC é a de se o contrato de trabalho pode ser objecto de modificaçóes durante o período em que se encontra suspenso.

\footnotetext{
${ }^{42}$ Năo se exige uma execução ininterrupta do contrato de trabalho, com a que não prejuxtica a contagem do prazo a eventual suspensāo do contrato de traballoo. Pretende-se com a exigencia de efectiva execução do contrato de trabalho täo só impedir fraudes, como por exemplo, de logo após a celebração do contrato de trabalho se acordar na sua suspensão, não havendo, assim, qualquer execuçăo do contrato ou se apor no contrato uma data anterior to do início efectivo do contrato de trabalho.
} 
Não se questionará que todas as modificações que pressuponham a efectiva prestação do trabalho são insusceptíveis de se produzirem durante o período de suspensão. $O$ mesmo não se dirá daqueles factos evolutivos ou mesmo modificativos que, não pressupondo a efectiva prestaçăo do trabalho, todavia estão ligados à duração do mesmo. É o caso, por exemplo, das diuturnidades que se vençam durante o período de suspensăo ou das promoções attomáticas que deveriam operar durante o mesmo período de suspensão, as quais nada impedem que se verifiquem se bem que só produzam efeitos no momento em que cesse a suspensão.

Por último cabe referir que os dois contratos cumulados, porque autónomos, têm sortes diferentes. Assim, cessando o contrato de administração por qualquer causa, mesmo destituição, năo cessará o contrato de trabalho que, pelo contrário, verá ressurgir toda a sua eficácia ${ }^{43}$.

\subsection{Os Gerentes das sociedades por quotas}

Diversamente do que acontece com as sociedades anónimas dotadas com conselho de administração, não existe qualquer norma que próba ou permita e regulamente o cúmulo de membro da gerência com o exercício de funções subordinadas ao abrigo de contrato de trabalho ou a celebração desse contrato durante o período para que foram designados.

Como acima expusemos ${ }^{4}$, não vemos obstáculo lógico intransponível a essa cumulação, por ser possível verificar-se a subordinação jurídica, característica essencial do contrato de trabaho. Afastadas, in limine, estão somente aquelas situações de gerência singular em que o gerente é o sócio maioritário, por nestes casos, de facto, não existirá o vínculo de subordinação jurídica. Em todas as outras situações, quer de gerência plural e, dentro desta, quer o gerente seja sócio quer seja estranho, quer de gerência singular, desde que o gerente năo seja sócio maioritário, é de admitir a cumblação, verificada que seja, in casu, a subordinação jurídica, sempre possível pelas razóes já referidas ${ }^{45}$.

\footnotetext{
${ }^{43} O$ que pode acontecer é que o mesno facto que serve de justa causa de destituição seja também fundamento para a cessação do contrato de trabalho por despedimento.

${ }^{4}$ Pp. 23 ess.

${ }^{45} \mathrm{Pp} .23$ ess.
} 
Claro está que o contrato de trabalho deve corresponder a um posto de trabalho efectivo, a uma função real e concreta, distinta da função de administração, exercida, como se disse, em posição de subordinação quer relativamente à gerência plural ou aos outros gerentes quer ao colégio dos sócios ou respectiva maioria.

De referir, por último, que nas sociedades por quotas a situação de cumulação pode não decorrer da celebração directa de um contrato de trabalho. Isso sucede se for estipulada no contrato de sociedade uma obrigação acessória, cujo objecto consista na prestaçt̃o de uma actividade de natureza laboral. Neste caso, por o conteúdo da obrigação corresponder ao de um contrato típico, nos temos do art art $209 .^{\circ}, n^{\circ}$ 1, in fine, do CSC, aplicar-se-á a regulamentação própria desse tipo de contrato e logo do contrato de trabalho ${ }^{46}$.

De referir, por último, que a cumulação pode resultar da lei, como será o caso de todos ou alguns dos sócios serem trabalhadores da sociedade e faltarem definitivamente todos os gerentes, situação em que todos os sócios, por força do disposto no art. $253^{\circ}, \mathrm{n} .{ }^{\circ} 1$, do CSC, assumirão os poderes de gerência até que sejam designados os gerentes.

Por tudo exposto, entendemos não ser de aplicar, por analogia, o art. 398." do CSC às sociedades por quotas.

\section{CONCLUSÕES}

1. A relação de administração nasce de um contrato, resultante da fusão de duas declarações de vontade, sendo uma a nomeação pela sociedade e outra a aceitação pelo nomeado, não obstante o conteúdo desse contrato ser, em parte, pré determinado pela lei.

2. O contrato de administração deverá ser qualificado como um contrato de prestação de serviços sui generis.

3. Poderá, no entanto, constituir um verdadeiro e próprio contrato de trabalho se, havendo remuneração, à sociedade for atribuído o poder

4 Ena sentido contrário J. PJnto Furtado, Curso de Direito das Sociedades, 4 ; edição, Almedina, Coimbra, 2001, p. 105. 
de organizar a execução do trabalho, mormente pela fixação do tempo de trabalho a prestar e do modo de o executar.

4. Por imperativo legal (art. 398." do CSC), a cumulação entre a qualidade de administrador e de trabalhador subordinado só é possível, nas sociedade anómimas, quanto o contrato de trabalho é pré-existente à designação como administrador e tem uma duração superior a um ano.

5. No entanto, esse contrato de trabalho verá a sua eficácia suspen. sa durante o período de cumulaç̃̃o.

6. Já quanto às sociedades por quotas a cumulação é sempre possível, verificado o vínculo de subordinação jurídica, o qual só será de afastar quanto a gerentes que sejam, em simultâneo, sócios maioritários. 


\section{BIBLIOGRA TIA}

CORREIA, Luís Brito - Os Administradores das Sociedades Anónimas, Coimbra, 1993. 1989.

- Direito Comercial, 2. ${ }^{\circ}$ Vol. - Sociedades Comerciais, AAFDL,

FERNANDES, A. L. Monteiro - Noçöes Fundamentais de Direito do Trabalho, Vol. 1, 3. ed., Coimbra, 1979. 1999.

FURTADO, J. Pinto - Curso de Direito das Sociedades, Coimbra,

LABAREDA, João - Direito Societário Portuguess - Algumas Questōes, Lisboa 1998.

RODRIGUES, Ilídio Duarte - A Administração das Sociedades por Quotas e Anónimas - Organização e Estatuto dos Administradores, Lisboa, 1990.

TELLES, Inocêncio Galvão - Contratos Civis, in BMJ, n. 83 .

VENTURA, Raúl - Sociedade por Quotas - Comentário ao Código das Sociedades Comerciais, Vols. I, II e III, Coimbra, 1991

XAVIER, Vasco da Gama Lobo - Anulação de Deliberação Social e Deliberaçöes Conexas, Coimbra, 1976. 